\title{
Quiet Healing
}

\author{
Peter A. de Schweinitz, MD
}

Both physicians and patients want deeply healing doctor-patient relationships. Too often, though, the ever-expanding demands of medical practice combine with the defenses of the patient to create doctorpatient isolation. Eastern and Western cosmologies and traditions may encourage different approaches to human interaction and healing. At times, probing the patient with more questions may open up a story vital to transformative healing. However, this narrative essay uses a personal experience as a patient of a Japanese traditional healer and Zen practitioner to explore the value of a quiet approach to patient care. (J Am Board Fam Med 2012;25:547-549.)

Keywords: Alternative Medicine, Complementary Medicine, Cross-Cultural Comparison, Japan, Personal Narratives, Physician Patient Relationship, Spirituality

"The poem springs from the half-spoken words of such patients as the physician sees from day to day."-William Carlos Williams ${ }^{1}$

What do we do with the young alcoholic who presents during follow-up with a bleeding ulcer? He sits before us, stone-faced, asking for a renewal of his proton pump inhibitor. What do we say to the elderly woman who, despite ongoing angina, refuses to quit smoking? "Makes you want to shake these people, wake them up," says one of my colleagues. I have felt this impulse myself. Indeed, sometimes the psychosocial issues of medicine seem to interfere with clinical guidelines like free air during an ultrasound. At some level, however, physicians recognize that, algorithms notwithstanding, the psychosocial issue-the "life lesion"-is not just a nuisance, it is the matter itself. We feel uneasy, but we do not know how to proceed. Do we take up the psychotherapeutic pick axe and chip away at the boundaries, or do we stick to a discussion of medications and side effects? Or, is there another way?

This article was externally peer reviewed.

Submitted 12 September 2011; revised 3 November 2011; accepted 14 November 2011.

From the Department of Family and Preventive Medicine, University of Utah, Springville.

Funding: none.

Conflict of interest: none declared.

Corresponding author: Peter A de Schweinitz, MD, Department of Family and Preventive Medicine, University of Utah, 1767 E. Town and Country, Springville, UT 84663 (E-mail: p_de_schweinitz@hotmail.com).
Before I entered medical school, I was a conflicted young husband who lay at the feet of Kyoko Arisaka, a thick-boned, middle-aged woman who lived in the shadow of the Daibutsu, a 13th century bronze Buddha who rests in the Lotus position on a prominent hill overlooking the city of Kamakura. At the time of our visit, I had been suffering with a cough and shortness of breath for 6 months. The sickness had taken half my voice, making it hard to function as an after-school English teacher. The neighborhood internist had listened to my lungs, taken a radiograph, and given me both Western medicines and Eastern herbs. When the medicines didn't work, I didn't return for follow-up. Though suffering in other ways too, I pictured myself powerful and good, immune almost, to the ordinary pains of life: I was a white, upper-middle-class man in his early 20s.

Rebecca and I arrived by train during the late winter, after the snow had melted. Without fanfare, Mrs. Kamakura welcomed us and led us to a room upstairs, where we dropped our bags. We then headed by foot away from the ocean and up the gentle hill to the Kotokuin Temple, the home of the Great Buddha. We climbed his spiral staircase and, from the slits in his tranquil eyes, looked out over the city. We saw red-lit teriyaki shops, barber posts, bars, uniformed children riding bicycles, temples, and surfers straddling boards in the ocean. We walked home at dusk.

After eating Mr. Arisaka's curry, our spouses retired upstairs, leaving my middle-aged hostess 
and me together downstairs on the tatami mat in the living room. After treating me to a PBS documentary about molecular genetics, she told me to lie supine on the floor. Having seen none of the usual trappings of Oriental medicine, with its meridians, needles, moxibustion, and herbs, I wondered what she had to offer.

Without so much as a chief complaint, however, she commenced. Grasping me firmly by the ankles, she swung me to and fro.

"Nani o shite iru n desu ka?" I queried. I fancied myself an amateur anthropologist of the Eastern tradition.

"I'm aligning your spine," she replied simply.

Mrs. Arisaka had the strength of an athlete half her age. But leverage counts, so she took one step closer, locked my ankles above her hips, and rocked more firmly now. After several minutes of swaying, my lower back, a former victim of disk disease, felt loose and relaxed.

"Turn over," she ordered.

As I took in the smell of curry, my eyes wandered about the room. The typical Japanese woman keeps shoes on shelves like numbers in a spreadsheet, but Mrs. Arisaka did not: notebooks, cushions, and the occasional pencil felt at home on the traditional mat.

I closed my eyes, then opened them a crack. Craning my neck subtly, I spied on the peculiar healer. Still as the Daibutsu, she knelt by my side, eyes closed. By the angle of her elbows and because I couldn't feel her touch, I figured her hands must be hovering somewhere over my low back. The only detectable sounds were her breathing and mine.

The year had been hard on our marriage. Although I was fluent, Rebecca, an introvert who felt embarrassed by her limited Japanese, was stuck teaching in a cold middle school and living in a traditional neighborhood in which few people spoke English. By the time she arrived home by train, I had often already driven off through the rice fields in our tiny white van. Life was not without its pleasant moments spent discovering mountain villages, visiting a woodsy temple, or eating Japanese pancakes in Kyoto, but quite often when we saw each other, we bickered, or outright fought, and when we did not, there was lingering tension.

Mrs. Arisaka had not moved from my side. What would come next-a chiropractic knee to the back? Truth be told, I would prefer a massage. I looked at
Mrs. Arisaka's sharply bent knee, wondered if the Japanese were born so flexible, tried to read the Chinese characters on the book to her side. Finally, studying the fibers in the mat, I drifted into reverie. Of what, I don't recall.

Suddenly my own voice stirred me. "Kenko towa ienai," I heard myself say. "Health, it can't be said." I suppose what I meant was, "I'm not healthy," but Japanese is a permissive language that allows such indirect, noncommittal statements devoid of pronouns. Though I wondered how the words had arrived, as soon as I spoke them, I knew them to be true, not just about my cough, but in some sort of global sense. As Mrs. Arisaka continued to breath, something worked in my chest.

"Kenko towa ienai," she echoed back.

I saw my young father in the backyard, chastising me for losing the new, purple bike he'd built for me; Mom in the kitchen, throwing a pen at me in my impertinence; now, just last month, the plastic siding of a Japanese carport cracked open by my soccer ball; and Rebecca, sitting on the floor in the corner of our Japanese living room, hugging her knees against my cutting words. My chest filled with, or rather opened to, what? Sorrow?

"Kenko towa ienai," I repeated. I felt as if some stranger, one far more vulnerable and honest than me, had taken control of my diaphragm, my throat.

"Kenko towa ienai," she echoed back.

For the next several minutes a warm fluid worked in me, unpacking many things I had not dared to know or feel. Afterward, we knelt together on the mat. "What were you doing with your hands?"

"Breathing through them," she said.

I extended my fingers, imagining.

In the morning Rebecca and I visited an island with a shrine. Mimicking the Japanese, I fanned healing smoke from a giant black pot onto my face and scalp, then wrote and placed a paper prayer on the wall. We hiked the rocky periphery of the island and then, in the early afternoon, gathered our belongings and walked to the train station.

Back home by Lake Biwa, the cough went away, most likely because, as spring arrived, we used the kerosene heater less and less. And my marriage began to shift, albeit slowly. Over years, the peaceful days increased, and even during the more turbulent times, the memory of the welling in my chest remained. 
Almost 20 years later, a middle-aged woman with tennis shoes, jeans, and a weathered face sits before me in the sparse "healing room" of the tribal clinic. "Just woke up with it," she says, rubbing her neck. She rolls her head, looks to the left and right. I press on the strap muscles. "Ow," she says, halfheartedly. The pain is not substantial. "Any numbness or tingling in your hands?" I ask. No. The problem seems minimal, unworthy, almost, of our time. Maybe a muscle relaxer before bed will do the trick. "You sleeping OK?" I say.

I look down and, for a moment, forget the templates on the computer and the line of patients in the lobby. When I look up, I see that her eyes have welled with tears. We've never met before today. She stammers and then shuts her mouth. We look at each other. "Ever since my son died," she says, "I haven't been able to sleep."

How do we serve the patient with the alcoholic ulcer, the cigarette angina, and the posttraumatic fibromyalgia? Are these patients the exception or the rule? The billing system, International Classification of Diseases codes, and productivity bonuses suggest that patients are an impersonal list of disconnected problems to be solved through evidencebased guidelines. We race through the checklists, all the while documenting the hard work we've accomplished. Our world and that of Mrs. Arisaka are very different. What use could she be to the busy family physician?

It is true: I have set Mrs. Arisaka up as a saint. But she is a useful saint, one that protects, encourages, and reminds. She knows the limitations of my circumstance-I cannot feed my patients, lodge them, or show them a PBS documentary. She forgives my imperfections. While my mind races wildly from social history to review of systems to physical examination and back, she waits, eyes closed. In the pause after my cell phone has interrupted, she whispers, "Here, be silent. Look away for a bit."

"Here, echo back," she suggests. "Now shut your trap." Ask my patients-I rarely hear her advice. I don't think of her everyday or even every week. On occasion, though, a sigh, the truncation of a sentence, or downturned eyes remind me of the smell of curry, the texture of the tatami, and the view from the statue's eyes.

Looking back on my time in Kamakura, it was more than the session alone. What mattered too, were the cobblestone roads, the paper prayers, the curry rice, and the messy house. Kamakura introduced a timeless safety, which over 2 decades has slowly diffused through my circuitry to influence, in subtle ways, my patient interactions. When a cocky young man comes to see me with heartburn, maybe, or a shoulder that won't throw softballs anymore, sometimes I ask about his childhood, his stress level, and his romantic life. But sometimes I don't. Mrs. Arisaka didn't that day. Neither did she screen for depression, perform a review of systems, or probe my satisfaction with work. She knelt by my side and breathed through her hands-a Buddha with arms outstretched.

The author wishes to acknowledge the grace, patience, and enduring love of his wife, Rebecca, the warm hospitality of the Arisaka family, and the generous editorial support of Alistair Bahar, and Rebecca de Schweinitz.

\section{Reference}

1. Williams WC. The practice. In: Reynolds R, Stone J, eds. On doctoring: stories, poems, essays. New York: Simon \& Schuster; 1991. 